\title{
Penicillinase and Ampicillin Resistance in a Strain of Escherichia coli
}

\author{
By J. T. SMITH \\ Department of Bacteriology, Guy's Hospital Medical School, London, S.E. 1
}

(Received 4 June 1962)

\section{SUMMARY}

\begin{abstract}
A penicillinase-positive variant was isolated from a penicillinasenegative strain of Escherichia coli during 'training' towards ampicillin resistance. The penicillinase activity of the variant was increased tenfold when the organisms were disrupted in a Milner press or treated with toluene, suggesting the presence of a permeability barrier. The enzyme released by disrupting the organisms was not precipitated by centrifugation nor removed by filtration. The penicillinase activity of toluene-treated organisms was easily removed by centrifugation. Disruption of the organisms released enzyme into solution whereas it remained intracellular in toluene-treated organisms. The variant strain, although resistant to over $200 \mu \mathrm{g}$. ampicillin $/ \mathrm{ml}$., did not appreciably destroy it; of other penicillins tested only penicillins $G$ and $V$ were readily destroyed. The enzyme was a 'penicillinase' ( $\beta$-lactamase) since the product was penicilloic acid. The enzyme was not inducible: exposure of organisms to 6-aminopenicillanic acid or phenoxybenzylpenicillin produced a threefold increase in penicillinase activity not due to true induction but to an increased permeability. The penicillinase of this strain of $E$. coli thus differs qualitatively and quantitatively from other penicillinases.
\end{abstract}

\section{INTRODUCTION}

Penicillinase produced by Gram-negative and other bacteria was first described by Abraham \& Chain (1940). However, until recently the interaction between penicillin and Gram-negative bacteria did not receive much attention because penicillin $\mathbf{G}$ was not highly active against such organisms. Much greater activity against these is shown by ampicillin ( $\alpha$-aminobenzylpenicillin; Penbritin, BRL 1341), a new semi-synthetic penicillin described by Rolinson \& Stevens (1961). The present paper describes a study of resistance and penicillinase in a strain of Escherichia coli.

\section{METHODS}

Penicillins. Penicillin G was obtained from Glaxo Laboratories Ltd. (Greenford, England). Penicillin V, phenethecillin ('Broxil'), methicillin ('Celbenin'), ampicillin ('Penbritin') 5-methyl-3-phenyl-4-isoxazolyl-penicillin (BRL 1400, P 12) and 6aminopenicillanic acid from Beecham Research Laboratories (Brockham Park, Surrey), phenoxypropyl penicillin from Pfizer Ltd. (Folkestone, Kent) and phenoxybenzyl penicillin (Penspek) from Distillers Co. Ltd. (Biochemicals) (Speke, Liverpool).

Measurement of antibacterial activity. One drop (0.02 $\mathrm{ml}$.) of a $4 \mathrm{hr}$. infusion broth culture was inoculated into $2 \mathrm{ml}$. of infusion broth containing serial dilutions of antibiotic. The results were read after incubation overnight at $37^{\circ}$. 
Measurement of penicillin destruction. (a) Production of acid from destruction of penicillin $G$ was determined qualitatively by the method of Knox \& Smith $(1961 a)$. Organisms were grown overnight on cellulose acetate membranes (Oxo Ltd.) on nutrient agar and transferred to a pad of three filter-papers moistened with a solution of penicillin G containing 25,000 units $/ \mathrm{ml}$. in Andrade's indicator (2\%). After incubation at $37^{\circ}$ for 2-3 $\mathrm{hr}$. penicillinase-producing colonies developed a pink colour due to production of penicilloic acid. Acid is also produced by amidasecatalysed destruction of penicillin $\mathbf{G}$ giving 6 -aminopenicillanic acid, but in practice a positive result indicates penicillinase activity.

(b) Microbiological activity of penicillin was estimated by determining the zone size given by $0.1 \mathrm{ml}$. of various dilutions of the antibiotic in holes cut in agar plates. The test organism used was Sarcina lutea (ATCC 934).

(c) Destruction of penicillin by amidase was tested for by the method of Batchelor, Chain, Richards \& Rolinson (1961). This method relies on the fact that at pH 2.0 penicillin $\mathrm{G}$ can be extracted by butyl acetate, leaving any 6 -aminopenicillanic acid, when present, in the aqueous phase. The latter was then estimated by the hydroxylamine method of Boxer \& Everett (1949).

(d) Destruction of penicillin by penicillinase was followed at a penicillin concentration of $2 \mathrm{mg} . / \mathrm{ml}$. at $37^{\circ}$ and $\mathrm{pH} 7 \cdot 4$ in infusion broth. Cultures were grown overnight at $37^{\circ}$ in infusion broth and the organisms harvested and washed twice in infusion broth by centrifugation at $2000 \mathrm{~g}$ for $10 \mathrm{~min}$. Sodium $p$-chlormercuribenzoate was added to $0.001 \mathrm{M}$ to prevent induction of penicillinase during the experiment (Steinman, 1961 $a, b$ ). The penicillin remaining was determined by the hydroxylamine method of Boxer \& Everett (1949).

Tests of penicillinase induction. Cultures were grown overnight in infusion broth at $37^{\circ}$ containing various concentrations, up to $1000 \mu \mathrm{g} . / \mathrm{ml}$. of the penicillin being tested for inducing ability. The organisms were then centrifuged down, washed twice with $0.001 \mathrm{M}$ - $p$-chlormercuribenzoate in infusion broth and resuspended at similar optical densities by using an EEL nephelometer. The rate of destruction of penicillin $\mathrm{G}$ was then determined by the hydroxylamine method.

Organisms. The organism used in this study was a strain of Escherichia coli isolated from a urinary-tract infection, laboratory reference no. 214. This organism (strain 0 ) was sensitive to $7 \cdot 5-10 \mu \mathrm{g}$. ampicillin $/ \mathrm{ml}$. by the tube dilution method and did not destroy penicillin $G$ when tested qualitatively by the membrane technique. When strain $\mathbf{O}$ was trained to become resistant to ampicillin by serial subculture on solid ampicillin-containing media a variant was isolated which was resistant to $230 \mu \mathrm{g}$. ampicillin $/ \mathrm{ml}$. This variant (strain $\mathrm{T}$ ) destroyed penicillin $\mathrm{G}$ when tested by the membrane technique.

Strains $\mathbf{O}$ and $\mathbf{T}$ grew at similar rates and gave the same biochemical reactions: acid and gas were produced in glucose, mannitol, dulcitol, lactose or maltose, and no reaction was observed in adonitol, inositol, sucrose, gelatin, urea, arabinose, phenylalanine or salicin. Both strains were indole-positive, Voges-Proskauer- and malonate-negative and were motile. They did not produce $\mathrm{H}_{2} \mathrm{~S}$ and did not grow when ammonium citrate was the sole carbon source; but they did produce acid and gas in MacConkey broth at $44^{\circ}$. Rabbit antisera prepared against each strain exhibited cross-agglutination at similar titres (1/1000). Each strain completely absorbed antibodies from both heterologous and homologous antisera. 


\section{RESULTS}

Antibacterial activity of penicillins against Escherichia coli no. 214 strains $O$ and $T$

The minimum inhibitory concentrations of various penicillins using the tube dilution method are shown in Table 1 . It can be seen that strain $\mathrm{T}$ was more resistant than strain $\mathbf{O}$ to all the penicillins tested.

Table 1. Minimum inhibitory concentrations obtained with various penicillins

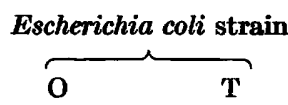

Penicillin

Ampicillin

6-aminopenicillanic acid

$\mathbf{G}$

$\mathbf{V}$

Phenoxybenzyl-

5-Methyl-3-phenyl-4-isoxazolyl-

Phenoxypropyl-

Phenoxyethyl-

Methicillin

$\overbrace{10}^{\mu \mathrm{g} . / \mathrm{ml} .}$

Table 2. Rates of destruction of penicillins as percentages of rate obtained with penicillin $\boldsymbol{G}$

\begin{tabular}{|c|c|c|c|}
\hline Penicillin & $\begin{array}{c}\text { Staphylococcus } \\
\text { aureus } \\
\text { strain E3 }\end{array}$ & $\begin{array}{c}\text { Bacillus } \\
\text { cereus } \\
\text { NRRL } 569\end{array}$ & $\begin{array}{c}\text { Escherichia } \\
\text { coli } \\
\text { strain } \mathrm{T}\end{array}$ \\
\hline $\mathbf{G}$ & $100(696)$ & $100(560)$ & $100(2)$ \\
\hline $\mathbf{V}$ & 110 & 117 & 82 \\
\hline Phenoxyethyl- & 100 & 103 & 7 \\
\hline Phenoxypropyl- & 71 & 56 & 4 \\
\hline Ampicillin & 198 & 156 & 3 \\
\hline Phenoxybenzyl- & 167 & 91 & $\mathbf{5}$ \\
\hline Methicillin & 1 & $\mathbf{1}$ & 7 \\
\hline 5-Methyl-8-phenyl-4-isoxazolyl- & 1 & $\mathbf{1}$ & 2 \\
\hline 6-Aminopenicillanic acid & 1 & 3 & $\mathbf{5}$ \\
\hline
\end{tabular}

Figures in parentheses indicate the absolute values for the rates of hydrolysis of penicillin $G$ in $\mu \mathrm{g} . / \mathrm{ml} . / \mathrm{min} . / 10^{\circ}$ organisms.

\section{Destruction of penicillins by Escherichia coli no. 214 strain $T$}

The ability of strain $\mathbf{T}$ to destroy penicillins was investigated and it was found to destroy penicillin $\mathrm{G}$ when tested by the hydroxylamine assay method. The product was identified as benzylpenicilloic acid by paper chromatography. The presence of amidase was tested for by the method of Batchelor et al. (1961) and the organism was found not to possess this type of enzyme. About $30 \%$ of the penicillinase activity was found in the culture medium; thus it seems that the penicillinase was mainly intracellular.

The results (Table 2) show the activity of the penicillinase of an intact untreated suspension of strain $\mathbf{T}$ against various penicillins; also included are results with a suspension of Staphylococcus aureus strain E3 (Knox, 1960; Knox \& Smith, 1961 b) grown overnight in $0.5 \mu \mathrm{g} . / \mathrm{ml}$. of methicillin as an inducing agent and the super- 
natant fluid from a culture of Bacillus cereus NRRL 569 grown overnight in $5 \mu \mathrm{g}$. methicillin $/ \mathrm{ml}$. as an inducing agent. It can be seen that the penicillinases from these two organisms are fairly similar as regards hydrolysis of various penicillins except for the rates of destruction of 6-aminopenicillanic acid and phenoxybenzyl/ penicillin. Both types of penicillinase destroyed ampicillin much more rapidly than they destroyed penicillin $G$ and their absolute activity was much greater than the penicillinase of strain $\mathbf{T}$; however, the latter organisms were not induced.

The penicillinase of Escherichia coli strain $\mathbf{T}$ had a much more restricted pattern of activity in that it only destroyed penicillins $\mathrm{G}$ and $\mathrm{V}$ to any appreciable extent. It had a very low but significant activity against ampicillin, which was so readily destroyed by the other two enzymes, when tested by the hydroxylamine and microbiological assay techniques. No increase in the rate of destruction of ampicillin was found at substrate concentrations as high as $15 \mathrm{mg} . / \mathrm{ml}$. (about $\mathrm{M} / 25$ ).

\section{Induction of penicillinase in Escherichia coli no. 214 strain $T$}

Induction of the penicillinase in strain $T$ was investigated. The results are shown in Table 3. It can be seen that induction with all the penicillins tested was of a low order; staphylococci can be induced to increase their rate of enzyme production 50 times (Knox \& Smith, 1962) and Bacillus cereus can possess several hundred-fold more enzyme when induced (Pollock, 1952; Steinman, 1961 $a, b$ ).

Table 3. Inducing ability of different penicillins

$\begin{array}{lcc} & \begin{array}{c}\text { Concentration of } \\ \text { penicillin } \\ \text { tested for } \\ \text { induction } \\ (\mu \mathrm{g} / \mathrm{ml})\end{array} & \begin{array}{c}\text { Ratio of induced } \\ \text { to basal } \\ \text { penicillinase } \\ \text { activity of } \\ \text { intact } \\ \text { organisms }\end{array} \\ \text { Ampicillin } & 100^{*} & \mathbf{1 \cdot 0 0} \\ \text { 5-Methyl-3-phenyl-4-isoxazolyl- } & 1000 & \mathbf{1 \cdot 0 0} \\ \text { V } & 1000 & \mathbf{1 \cdot 4 2} \\ \text { G } & 500^{*} & \mathbf{1 \cdot 0 0} \\ \text { Phenoxyethyl- } & 1000 & \mathbf{1 \cdot 6 4} \\ \text { Phenoxypropyl- } & 1000 & \mathbf{1 \cdot 6 4} \\ \text { Methicillin } & 1000 & \mathbf{1 \cdot 6 4} \\ \text { 6-Aminopenicillanic acid } & \mathbf{3 0 *} & \mathbf{8 \cdot 0 0} \\ \text { Phenoxybenzyl- } & \mathbf{5 0 0 *} & \mathbf{3 \cdot 4 5}\end{array}$

* The organism did not grow well enough in higher concentrations of these antibiotics to test for induction.

\section{Penicillinase activity of disrupted Escherichia coli no. 214 strain $T$}

The effect of disrupting the organisms of strain $T$ in a press was investigated. A suspension of strain $\mathbf{T}$ was taken and disrupted in a press described by Milner, Lawrence \& French (1950) and modified by Wimpenny (1962), at $4^{\circ}$ and $3000 \mathrm{lb} . /$ sq.in. The broken organisms were then tested for destruction of various penicillins. The broken organisms destroyed penicillin $G$ at a rate about 10 times the rate obtained with intact organisms but did not destroy ampicillin to any appreciable extent. The enzyme released by breaking strain $T$ in the press was further investigated. The enzyme was not precipitated when centrifuged at $83,000 \mathrm{~g}$ at $\mathbf{2}^{\circ}$ for 
90 min.; it passed through an Oxoid filter membrane of mean pore size of $0.5-1 \cdot 0 \mu$; it was destroyed by boiling for $10 \mathrm{~min}$. or by incubation at $37^{\circ}$ overnight in $0.2 \%$ trypsin.

\section{Penicillinase activity of toluene-treated Escherichia coli no. 214 strain $T$}

Since the penicillinase activity of strain $\mathbf{T}$ was increased tenfold by disruption of the organisms the effect of toluene treatment was investigated. Organisms were treated with toluene, samples broken in the press and the activity of both suspensions tested against penicillin G. Both suspensions were about 10 times more active than untreated organisms. The toluene treatment did not lyse the organisms (as judged by nephelometry and microscopy), whereas disruption of the organisms with the press causes the optical density to fall by some $60 \%$. It was found that the penicillinase activity of toluene-treated organisms was precipitated by centrifuging at $2000 \mathrm{~g}$ for $10 \mathrm{~min}$.

Penicillinase activity of disrupted induced Escherichia coli no. 214 strain $T$

The effect of disrupting induced organisms in the press was examined. Strain $\mathbf{T}$ was grown overnight in infusion broth and infusion broth containing $30 \mu \mathrm{g}$. 6-aminopenicillanic acid $/ \mathrm{ml}$. The organisms were centrifuged down, washed twice in $10^{-3} \mathrm{M}$ $p$-chlormercuribenzoate in broth and resuspended at similar opacities by using an EEL nephelometer. Portions of 6-aminopenicillanic acid-treated and of untreated organisms were broken in the press at $3000 \mathrm{lb}$./sq.in. at $4^{\circ}$ and all suspensions were tested for destruction of penicillin G. The rates of destruction are shown in Table 4.

Table 4. Penicillinase activity of intact and disrupted 6-aminopen
acid-treated organisms
$\begin{array}{cc}\text { Destruction of } \\ \text { penicillin } \mathrm{G}, \\ \mu \mathrm{g} . / \mathrm{ml} / \mathrm{min} \text {./ } \\ \mathbf{m g} . \text { dry } \\ \text { weight bacteria }\end{array}$
$\begin{array}{cc}\mathbf{3 \cdot 8 4} \\ \text { Intact untreated strain } \mathbf{T} & \mathbf{1 2 \cdot 2 4} \\ \text { Intact 6-aminopenicillanic } & \\ \text { acid-treated strain } \mathbf{T} & \mathbf{4 2 \cdot 0 0} \\ \text { Broken untreated strain } \mathbf{T} & \mathbf{4 2 \cdot 0 0} \\ \text { Broken 6-aminopenicillanic } & \\ \text { acid-treated strain T } & \end{array}$

It can be seen that the intact 6-aminopenicillanic acid-treated organisms possessed about 3 times the activity of intact untreated organisms. However, both treated and untreated organisms, when broken, possessed identical activities. Thus treatment with 6-aminopenicillanic acid had not caused any increase in total enzyme content. Similar results were obtained with organisms grown in $500 \mu \mathrm{g}$. phenoxybenzylpenicillin $/ \mathrm{ml}$. and with the toluene treatment in place of disruption of the organisms in the press.

Penicillinase activity of disrupted Escherichia coli no. 214 strain $O$

The presence of penicillinase in strain $O$ was investigated. Strains $O$ and $T$ were grown overnight in infusion broth. The organisms were centrifuged down and washed 
in $10^{-3} \mathrm{M}$ - $p$-chlormercuribenzoate in broth and resuspended at similar opacities by using an EEL nephelometer. A sample of each suspension was taken and disrupted in the press and the activity of the broken and intact strain $\mathbf{O}$ organisms compared with similarly treated strain $\mathbf{T}$ organisms. These results are shown in Table 5 . It can be seen that disrupted strain $O$ organisms showed a small amount of enzyme but not the intact ones. The total amount of enzyme in the strain $O$ was about one-fiftieth of the total amount of enzyme in strain $\mathbf{T}$.

Table 5. Penicillinase activity of intact and disrupted organisms

Destruction of
penicillin $\mathrm{G}$,
$\mu \mathrm{g} . / \mathrm{ml} . / \mathrm{min} .$,
per $\mathrm{mg}$. dry weight
of bacteria

Intact strain O
Broken strain O
Intact strain T
Broken strain T

$\mathbf{0}$

$0 \cdot 84$

$4 \cdot 22$

$\mathbf{4 2 \cdot 4 4}$

The penicillinase activity of strain $O$ released by disruption was found to be similar to the enzyme possessed by strain $\mathbf{T}$; it was heat- and trypsin-labile, not precipitated by centrifugation nor removed by filtration through an Oxoid filter membrane. The penicillinase activity was exposed by either breaking the organisms in a press or by toluene treatment. The activity of toluene-treated suspensions was sedimented by centrifugation at $2000 \mathrm{~g}$ for $10 \mathrm{~min}$. The enzyme of strain $\mathrm{O}$ destroyed penicillins $\mathrm{G}$ and $\mathrm{V}$ at similar proportional rates to those found with enzyme of strain $\mathbf{T}$ and was relatively inactive against any other penicillins.

\section{DISCUSSION}

As a result of 'training' Escherichia coli no. 214 strain $O$ to resist the antibacterial activity of ampicillin, strain $T$ was selected, and this strain possessed a total content of about 50 times more penicillinase than the parent strain. Both strains $\mathbf{O}$ and $\mathbf{T}$ gave similar biochemical reactions and serologically could not be separated. Therefore it seems likely that strain $T$ was a mutant of strain $O$. Further attempts to select a mutant from strain $\mathrm{O}$ with the characteristics of strain $\mathrm{T}$ have so far failed; therefore it seems that such a change is a rare event. Although the enzyme of strain $\mathbf{T}$ was relatively inactive against ampicillin, as compared with its activity against penicillin $\mathbf{G}$, it did destroy some. If the enzymes of both strain $\mathbf{O}$ and $\mathbf{T}$ are identical the fact that strain $T$ possessed much more enzyme than strain $O$ may explain the resistance of the former to ampicillin. Indeed the penicillinase activity of strain $\mathrm{O}$ was only demonstrable when the cells were disrupted or treated with toluene, whereas a tenth of the total penicillinase activity of the variant strain could be detected in intact cells. Thus the variant strain could have some sort of advantage over the parent strain in the presence of ampicillin.

Another possible way of explaining the increased resistance of the variant strain would be if the penicillinase had some essential metabolic function to the cell. The finding that the variant strain had about 50 times more enzyme might mean that this strain would have an advantage over the parent strain if the enzyme were also 
a site for antibiotic action. Indeed Abraham \& Chain (1940) stated that the number of bacteria found to contain an enzyme acting on penicillin points to the possibility that it may have a function in their metabolism.

Of course resistance to penicillin is not always due to penicillinase. Staphylococci trained to become resistant in vitro do not destroy penicillin $\mathrm{G}$ but become tolerant to it, whereas resistant strains isolated from clinical specimens possess penicillinase (Spink \& Ferris, 1945). The strain of Escherichia coli used here was trained to ampicillin resistance in vitro and it is quite possible that the ampicillin-resistant variant was resistant by a mechanism similar to that seen in staphylococci made resistant to penicillin G in vitro (Knox \& Smith, $1961 b$ ).

The behaviour of the enzyme found in the Escherichia coli strain $\mathbf{T}$ was different from that of penicillinases belonging to other species of micro-organisms which have been previously described.

(1) The penicillinase activity of strain $\mathrm{T}$ was increased by about tenfold by disrupting the cells or by toluene treatment, indicating the presence of a permeability barrier. Geronimus \& Cohen (1958) found that the cell membrane of penicillinaseproducing staphylococci did not present a barrier between penicillin $\mathbf{G}$ and the penicillinase, and Pollock (1961) obtained similar results with Bacillus subtilis. On the other hand, Novick (1962), using staphylococcal penicillinase, found that the extracellular enzyme had a higher affinity for penicillins $G$ and $V$ than the cell-bound enzyme, which could suggest that a permeability barrier may be present.

(2) When the organisms were broken in the press the penicillinase activity was not precipitated by centrifugation nor removed by filtration and therefore seems to be 'soluble'. Saz, Lowery \& Jackson (1961) found that the intracellular penicillinase of staphylococci was particulate as it was removed by centrifuging at $144,000 \mathrm{~g}$ for $15 \mathrm{~min}$. Sabath \& Finland (1962) found that the penicillinase from disrupted staphylococci could be removed by filtration through a bacteria-proof sintered glass filter.

(3) When the enzyme of either strain $O$ or $\mathbf{T}$ was exposed by toluene treatment it was easily precipitated by centrifuging down the cells, whereas the penicillinase activity of disrupted cells remained in the supernatant. Thus the penicillinase may be attached to the cell by a mechanism which is not associated with the permeability barrier, or toluene treatment may damage the permeability barrier sufficiently to allow access of penicillin $G$ to the penicillinase but not sufficiently to allow the enzyme out.

(4) The specificity pattern of the Escherichia coli penicillinase was much narrower than that of Staphylococcus aureus or Bacillus cereus penicillinases. It is interesting that it destroyed penicillin $\mathrm{V}$ twelve times more rapidly than phenoxyethylpenicillin which differs from the former in that it has one more methyl group in the sidechain.

(5) The penicillinase of the Escherichia coli strain T was not inducible. Treatment of the organisms with 6-aminopenicillanic acid or phenoxybenzylpenicillin did not give rise to a real increase in total enzyme content but caused a larger proportion $(3 / 10)$ of enzyme to be accessible to the substrate than the proportion $(1 / 10)$ of unmasked enzyme in untreated cells. Whether this is due to damage of the permeability barrier allowing the substrate easier access to the enzyme or due to an increased active transport mechanism, such as permease, across the permeability barrier is unknown. 
Grateful thanks are due to Beecham Research Laboratories for supplies of phenethicillin, $\alpha$-aminobenzylpenicillin, 5-methyl-3-phenyl-4-isoxazolylpenicillin and 6-aminopenicillanic acid, to Pfizer Ltd for phenoxypropylpenicillin, to Distillers Company Ltd for phenoxybenzylpenicillin and to Miss B. Whittamore for valuable technical help. I am particularly grateful to Professor R. Knox for encouragement and constructive criticism, and to Dr J. Mandelstam for suggesting toluene treatment.

\section{REFERENCES}

Abraham, E. P. \& Chain, E. B. (1940). An enzyme from bacteria able to destroy penicillin. Nature, Lond. 146, 837.

Batchelor, F. R., Chain, E. B., Richards, M. \& Rolinson, G. N. (1961). Formation of 6-aminopenicillanic acid from penicillin by enzymic hydrolysis. Proc. roy. Soc. B, $154,522$.

Boxer, G. E. \& Everett, P. M. (1949). The colorimetric determination of benzyl penicillin. Analyt. Chem. 21, 670.

Geronimus, L. H. \& CoHen, S. (1958). Further evidence for inducibility of staphylococcal penicillinase. J. Bact. 76, 117.

KNox, R. (1960). A new penicillin (BRL 1241) active against penicillin-resistant staphylococci. Brit. med. J. ii, 690.

Knox, R. \& Sмiтн, J. T. $(1961 a)$. Use of cellulose acetate membranes for detecting penicillinase-producing organisms. Nature, Lond. 191, 926.

KNox, R. \& SMrth, J. T. $(\mathbf{1 9 6 1} b)$. The nature of penicillin resistance in staphylococei. Lancet, ii, 520.

Knox, R. \& Smrth, J. T. (1962). Antibacterial activity, penicillinase stability and inducing ability of different penicillins. J. gen. Microbiol. 29, 471 .

Milner, H. W., Lawrence, N. S. \& French, C. S. (1950). Colloidal dispersion of chloroplast material. Science, 111, 633.

Novick, R. P. (1962). Staphylococcal penicillinase and the new penicillins. Biochem. $J$. 83, 229.

Pollock, M. R. (1952). Penicillinase adaptation in Bacillus cereus. An analysis of three phases in the response of logarithmically growing cultures to induction of penicillinase formation by penicillin. Brit. J. exp. Path. 33, 587.

Pollock, M. R. (1961). The measurement of the liberation of penicillinase from Bacillus subtilis. J. gen. Microbiol. 26, 239.

Rolinson, G. N. \& Stevens, S. (1961). Microbiological studies on a new broad-spectrum penicillin, 'Penbritin'. Brit. med. J. ii, 191.

Sabath, L. D. \& Finland, M. (1962). Sterile penicillinase from phage-lysed staphylococci. Nature, Lond. 193, 272.

SAz, A. K., Lowery, D. L. \& JAckson, L. J. (1961). Staphylococcal penicillinase. I. Inhibition and stimulation of activity. J. Bact. 82, 298.

SpINK, W. W. \& Ferris, V. (1945). Penicillin inhibitor from staphylococei which have developed resistance to penicillin in the human body. Proc. Soc. exp. Biol., N.Y. 59, 188.

Steinman, H. G. (1961 a). A biochemical comparison of 6-aminopenicillanic acid benzyl penicillin and 2,6-dimethoxyphenyl-penicillin. Proc. Soc. exp. Biol., N.Y. 106, 277.

Steinman, H. G. $(1961 b)$. Factors modifying induced formation of penicillinase in Staphylococcus aureus. J. Bact. 81, 895.

WIMPENNY, J. W. T. (1962). The effects of isonicotinic acid hydrazide and other drugs on synthetic mechanisms in mycobacteria. Ph.D. Thesis, University of London. 